\title{
PERBANDINGAN MODEL REGRESI BINOMIAL NEGATIF BIVARIAT DENGAN MODEL GEOGRAPHICALLY WEIGHTED NEGATIVE BINOMIAL BIVARIAT REGRESSION (GWNBBR) PADA KASUS ANGKA KEMATIAN BAYI DAN KEMATIAN IBU DI JAWA TENGAH
}

\author{
Yashmine Noor Islami ${ }^{1}$, Dwi Ispriyanti ${ }^{2}$, Puspita Kartikasari ${ }^{3}$ \\ ${ }^{1,2,3}$ Departemen Statistika, Fakultas Sains dan Matematika, Universitas Diponegoro \\ Email: yashminenoor13@gmail.com
}

\begin{abstract}
Infant mortality (0-11 months) and maternal mortality (during pregnancy, childbirth, and postpartum) are significant indicators in determining the level of public health. Central Java Province which has 35 regencies/cities is included in the top five regions with the highest number of infant and maternal mortality in Indonesia. The data characteristics of the number of infants and maternal mortality are count data. Therefore, the Poisson Regression method can be used to analyze the factors that influence the number of infants and maternal mortality. In Poisson regression analysis, there must be a fulfilled assumption, called equidispersion. Frequently, the variance of count data is greater than the mean, which is known as the overdispersion. The research, binomial negative bivariate regression is used as a solutions to overcome the problem of overdispersion in poisson regression. This method produce a global model. In reality, the geographical, sociocultural, and economic conditions of each region will be different. This illustrates the effect of spatial heterogeneity, so it needs to be developed into Geographically Weighted Negative Binomial Bivariate Regression (GWNBBR). The model of GWNBBR provides weighting based on the position or distance from one observation area to another. Significant variables for modeling infant mortality cases included the percentage of obstetric complications treated $\left(\mathrm{X}_{1}\right)$, the percentage of infants who were exclusively breastfed $\left(\mathrm{X}_{3}\right)$, and the percentage of poor people $\left(\mathrm{X}_{5}\right)$. Significant variable for modeling maternal mortality cases is the percentage of poor people $\left(\mathrm{X}_{5}\right)$. Based on the AIC value, GWNBBR model is better than binomial negatif bivariat regression model because it has a smaller AIC value.
\end{abstract}

Keywords: Infant Mortality, Maternal mortality, Overdispersion, Negative Binomial Bivariate Regression, GWNBBR

\section{PENDAHULUAN}

Angka kematian bayi dan kematian ibu merupakan salah satu indikator penting dalam menentukan tingkat kesehatan masyarakat. Keberhasilan pembangunan di suatu wilayah juga dapat dilihat dari angka kematian bayi dan angka kematian ibu (Dinkes Jateng, 2019). Provinsi Jawa Tengah yang memiliki 35 kabupaten/kota termasuk 5 besar daerah dengan jumlah kematian bayi dan kematian ibu tertinggi di Indonesia. Jumlah kematian bayi pada tahun 2018 di Jawa Tengah mencapai 4.481 kasus, sedangkan jumlah kematian ibu di Jawa Tengah pada tahun 2018 mencapai 421 kasus (Kemenkes RI, 2020).

Banyak faktor yang memengaruhi kematian bayi dan kematian ibu, antara lain persentase persalinan oleh tenaga kesehatan, persentase ibu bersalin mendapatkan pelayanan kesehatan nifas, persentase ibu hamil melaksanakan program K4, persentase ibu hamil yang mendapatkan tablet $\mathrm{Fe} 3$, persentase penanganan komplikasi kebidanan, persentase penanganan komplikasi neonatal, persentase bayi yang diberi ASI eksklusif, dan persentase rumah tangga berperilaku hidup bersih dan sehat (Fitriyanti dan Kurniawan, 2019). Metode statistik yang menganalisis hubungan antara suatu variabel dengan faktor yang memengaruhi adalah analisis regresi. Pada umumnya, regresi digunakan untuk menganalisis variabel respon yang berjenis kontinu, namun sering juga ditemui variabel respon yang berjenis diskrit (Long, 1997). Analisis yang digunakan untuk variabel respon diskrit adalah regresi poisson. Dalam analisis regresi poisson terdapat asumsi yang harus terpenuhi yaitu eqiudispersi. Sering kali data count memiliki variance yang lebih besar dari mean, atau biasa 
disebut fenomena overdispersion (Cameron \& Trivedi, 1998). Apabila terjadi overdispersion, regresi poisson tidak sesuai untuk memodelkan data. Salah satu metode yang digunakan untuk mengatasi overdispersion dalam regresi poisson adalah regresi binomial negatif bivariat. Namun metode ini menghasilkan model yang bersifat global. Pada kenyataannya kabupaten/kota di Jawa Tengah memiliki kondisi geografis, sosial budaya, dan ekonomi yang berbeda antar wilayah. Kematian bayi di Jawa Tengah menurut Prahutama, et al. (2017) dipengaruhi oleh jumlah sarana kesehatan (RS dan Puskesmas), jumlah tenaga medis (dokter dan bidan), persentase persalinan yang dilakukan dengan bantuan non medis (dukun bayi), persentase rumah tangga kumuh, kepadatan penduduk per $\mathrm{km}^{2}$, persentase rumah tangga ber-PHBS, persentase penduduk yang tidak punya jaminan kesehatan, persentase anak yang umurnya kurang dari 2 tahun yang diberi ASI eksklusif, dan rata-rata lama pemberian ASI. Sehingga analisis yang digunakan adalah model Geographically Weighted Negative Binomial Bivariate Regression (GWNBBR).

Berdasarkan uraian di atas maka dalam penelitian ini akan dianalisis kematian bayi dan kematian ibu di Jawa Tengah menggunakan regresi binomial negatif bivariat. Kemudian dianalisis menggunakan metode GWNBBR. Selanjutnya dilakukan pemilihan model terbaik dengan membandingkan model dari regresi binomial negatif bivariat dan GWNBBR menggunakan Akaike's Information Criterion (AIC).

\section{TINJAUAN PUSTAKA}

\subsection{Angka Kematian Bayi dan Angka Kematian Ibu}

Angka Kematian Bayi (AKB) merupakan jumlah kematian bayi (0-11 bulan) per 1.000 kelahiran hidup dalam kurun waktu satu tahun (Dinkes Jateng, 2019). Angka Kematian Ibu (AKI) adalah rasio kematian ibu selama masa kehamilan, persalinan, dan nifas yang sebabkan oleh kehamilan, persalinan, dan nifas atau pengelolaannya tetapi bukan karena sebab-sebab lain seperti kecelakaan atau terjatuh di setiap 100.000 kelahiran hidup (Kemenkes RI, 2020).

\subsection{Korelasi}

Menurut (Draper \& Smith, 1998) koefisien korelasi merupakan suatu indikator dalam hubungan linier antara 2 variabel. Hipotesis uji koefisien korelasi adalah sebagai berikut.

$H_{0}: \rho=0$ (Tidak terdapat hubungan linier antara $Y_{1}$ dan $Y_{2}$ )

$H_{1}: \rho \neq 0$ (Terdapat hubungan linier antara $Y_{1}$ dan $Y_{2}$ )

Statistik uji:

$$
\begin{aligned}
& t=\frac{r_{y_{1} y_{2} \sqrt{n-2}}}{\sqrt{1-r_{y_{1} y_{2}}^{2}}} \text { dengan } r_{y 1, y 2}=\frac{\sum_{i=1}^{n}\left(y_{1 i}-\bar{y}_{1}\right)\left(y_{2 i}-\bar{y}_{2}\right)}{\sqrt{\sum_{i=1}^{n}\left(y_{1 i}-\bar{y}_{1}\right)^{2} \sum_{i=1}^{n}\left(y_{2 i}-\bar{y}_{2}\right)^{2}}} \\
& \text { Tolak Hojika }\left|t_{\text {hit }}\right|>t_{\left(\frac{\alpha}{2} ; n-2\right)}(\text { McClave } \text { et al., 2018) }
\end{aligned}
$$

\subsection{Distribusi Poisson Bivariat}

Distribusi poisson bivariat adalah distribusi bersama variabel $Y_{1}$ dan $Y_{2}$ yang berdistribusi poisson dan saling dependen (Karlis \& Ntzoufras, 2005). Pengujian distribusi poisson bivariat dilakukan dengan pendekatan index of dispersion Test $\left(I_{B}\right)$ dengan hipotesis sebagai berikut.

$H_{0}$ : Variabel respons $\mathrm{Y}_{1}$ dan $\mathrm{Y}_{2}$ mengikuti distribusi poisson bivariat

$H_{1}$ : Variabel respons $\mathrm{Y}_{1}$ dan $\mathrm{Y}_{2}$ tidak mengikuti distribusi poisson bivariat

Statistik uji:

$I_{B}=\frac{n\left(\bar{Y}_{2} S_{Y_{1}}^{2}-2 m_{11}^{2}+\bar{Y}_{1} S_{Y_{2}}^{2}\right)}{\left(\bar{Y}_{1} \bar{Y}_{2}-m_{11}^{2}\right)}$

dimana

n: banyaknya observasi 
$\bar{Y}_{1}$ : nilai rata-rata variabel respons $\left(\mathrm{Y}_{1}\right)$

$\bar{Y}_{2}$ : nilai rata-rata variabel respons $\left(\mathrm{Y}_{2}\right)$

$S_{Y_{1}}^{2}=\frac{\sum_{i=1}^{n}\left(Y_{1 i}-\bar{Y}_{1}\right)}{n}$ dan $S_{Y_{2}}^{2}=\frac{\sum_{i=1}^{n}\left(Y_{2 i}-\bar{Y}_{2}\right)}{n}$

$m_{11}=\frac{\sum_{i=1}^{n}\left(Y_{1 i}-\bar{Y}_{1}\right)\left(Y_{2 i}-\bar{Y}_{2}\right)}{n}$

Tolak $H_{0}$ jika $\left|I_{B}\right|>\chi_{(\alpha ; 2 n-3)}^{2}$ (Best, 1999).

\subsection{Multikolinieritas}

Multikolinieritas berarti adanya hubungan linier yang sempurna atau pasti di antara beberapa atau semua variabel yang menjelaskan model regresi. Untuk mendeteksi multikolinieritas dapat diperiksa dengan menggunakan nilai VIF berikut (Gujarati, 2003).

$V I F_{k}=\frac{1}{1-R_{k}^{2}}$

$R_{k}^{2}$ merupakan koefisien determinasi untuk variabel prediktor ke- $k$ dengan variabel prediktor lainnya. Nilai VIF yang lebih dari 10 menandakan terjadinya multikolinieritas.

\subsection{Model Regresi Poisson Bivariat}

Model regresi poisson bivariat menurut Karlis dan Ntzoufras (2005) adalah sebagai berikut.

dimana

$$
\begin{gathered}
\left(Y_{1 i}, Y_{2 i}\right) \sim P B\left(\lambda_{1 i}, \lambda_{2 i}, \lambda_{0 i}\right) \\
\lambda_{j i}+\lambda_{0}=e^{\boldsymbol{x}_{i}^{T} \boldsymbol{\beta}_{j}} ; j=1,2
\end{gathered}
$$

$\boldsymbol{x i}^{T}=\left[\begin{array}{lllll}1 & x_{1 i} & x_{2 i} & \cdots & x_{p i}\end{array}\right]$

$\boldsymbol{\beta}_{j}=\left[\begin{array}{lllll}\beta_{j 0} & \beta_{j 1} & \beta_{j 2} & \cdots & \beta_{j p}\end{array}\right]^{T}, j=1,2$

\subsection{Overdispersi}

Overdispersi adalah suatu kejadian dimana nilai variance lebih besar daripada nilai mean (Cameron \& Trivedi, 1998). Pemeriksaan overdispersi menggunakan uji kesamaan model BPR dan BNBR dengan hipotesis sebagai berikut.

$H_{0}:$ Model BPR $=\mathrm{BNBR}$

$H_{1}:$ Model $\mathrm{BPR} \neq \mathrm{BNBR}$

Statistik uji:

$F_{\text {hit }}=\frac{D_{0} / d f_{0}}{D_{1} / d f_{1}}$

Tolak $H_{0}$ jika $F_{h i t}>F_{\left(\alpha ; d f_{0} ; d f_{1}\right)}$ (Hilbe, 2011).

\subsection{Model Regresi Binomial Negatif Bivariat}

Bila sepasang variabel random $Y_{1}$ dan $Y_{2}$ masing-masing berdistribusi binomial negatif diregresikan terhadap variabel prediktor $X_{1}, X_{2}, \ldots, X_{p}$, maka bentuk persamaan regresi binomial negatif bivariat dapat dinyatakan sebagai berikut (Famoye, 2010).

$$
\begin{gathered}
\left(Y_{1}, Y_{2}\right) \sim B N B\left(\mu_{1}, \mu_{2}, \alpha_{1}, \alpha_{2}, \Psi\right) \\
\mu_{j i}=\exp \left(\mathbf{x}_{i}^{T} \boldsymbol{\beta}_{j k}\right) ; i=1,2, \ldots, n ; j=1,2
\end{gathered}
$$

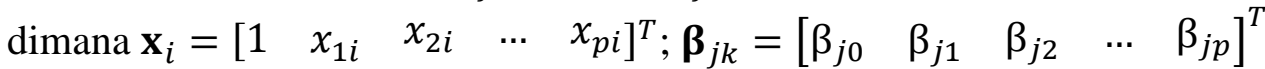

Estimasi parameter model regresi binomial negatif bivariat menggunakan metode maksimum likelihood dengan prosedur Newton Raphson.

Pengujian signifikansi parameter secara serentak menggunakan uji devians dengan hipotesis sebagai berikut.

$H_{0}: \beta_{j 1}=\beta_{j 2}=\cdots=\beta_{j p}=0 ; j=1,2$

$H_{1}$ : minimal ada satu $\beta_{j k} \neq 0 ; k=1,2, \ldots, p$

Statistik uji: 


$$
D=-2 \ln \left(\frac{L(\widehat{\omega})}{L(\widehat{\Omega})}\right)=2(\ln L(\widehat{\Omega})-\ln L(\widehat{\omega}))
$$

Tolak $H_{0}$ jika statistik uji $D>\chi_{[\alpha,(b-a)]}^{2}$.

Pengujian parameter secara parsial untuk mengetahui parameter mana saja yang memberikan pengaruh signifikan terhadap model dengan hipotesis sebagai berikut.

$H_{0}: \beta_{j k}=0$

$H_{1}: \beta_{j k} \neq 0 ; j=1,2 ; k=1,2, \ldots, p$

Statistik uji:

$$
z_{\text {hitung }}=\frac{\hat{\beta}_{j k}}{\operatorname{se}\left(\hat{\beta}_{j k}\right)}
$$

Tolak $H_{0}$ jika $\left|z_{\text {hitung }}\right|>z_{\alpha / 2}$ (Hilbe, 2011). Dimana $\alpha$ adalah taraf signifikansi.

\subsection{Heterogenitas Spasial}

Pengujian heterogenitas spasial dilakukan untuk melihat apakah terdapat kekhasan pada setiap lokasi pengamatan, sehingga parameter regresi yang dihasilkan berbeda-beda secara spasial. Pengujian hipotesis heterogenitas spasial menggunakan uji Glejser sebagai berikut. $H_{0}: \sigma_{1}^{2}=\sigma_{2}^{2}=\cdots=\sigma_{n}^{2}=\sigma^{2}$ (Tidak ada heterogenitas spasial) $H_{1}$ : minimal ada satu $\sigma_{i}^{2} \neq \sigma^{2} ; i=1,2, \ldots, n$ (Ada heterogenitas Spasial) Statistik uji:

$G=-\left(n-j-1-\frac{1}{2}(j-1)\right) \ln \left(\frac{\left|\sum_{\Omega}\right|}{\left|\sum_{\omega}\right|}\right) \sim \chi_{\alpha ; v}^{2}, v=j k ; j=1,2 ; k=1,2, \ldots, p$

$\Sigma_{\omega}$ adalah matriks varian kovarian di bawah $H_{0}$ dan $\Sigma_{\Omega}$ adalah matriks varians kovarian di bawah $H_{1}$ (Johnson \& Wichern, 2007). Tolak $H_{0}$ jika nilai $G>\chi_{\alpha ; p}^{2}$.

\subsection{Matriks Pembobot Geografis}

Keragaman spasial antara lokasi satu dengan lokasi lain ditunjukkan dengan adanya matriks pembobot $\mathbf{W}$ yang entri-entrinya merupakan fungsi dari jarak euclidean antar lokasi (Chasco et al., 2008). Pembentukan fungsi pembobot dari jarak euclidean salah satunya dapat menggunakan fungsi Adaptive Bisquare Kernel. Fungsi Adaptive Bisquare Kernel merupakan fungsi kernel dengan bandwidth yang berbeda pada setiap lokasi pengamatan. Fungsi Adaptive Bisquare Kernel dinyatakan pada persamaan sebagai berikut

$$
w_{i l}=\left\{\begin{array}{c}
\left(1-\left(\frac{d_{i l}}{h_{i}}\right)^{2}\right)^{2} \text { untuk } d_{i l} \leq h_{i} \text { dengan } d_{i l}=\sqrt{\left(u_{i}-u_{l}\right)^{2}+\left(v_{i}-v_{l}\right)^{2}} \\
0 \quad \text { untuk } d_{i l}>h_{i}
\end{array}\right.
$$

$d_{i l}$ : jarak euclidean antara lokasi $\left(u_{i}, v_{i}\right)$ ke lokasi $\left(u_{l}, v_{l}\right)$

$h_{i}$ : bandwidth pada lokasi ke-i

$u_{i}$ : koordinat latitude (lintang) pada lokasi ke-i

$v_{i}$ : koordinat longitude (bujur) pada lokasi ke-i

Bandwidth merupakan radius suatu lingkaran dimana titik yang berada dalam radius lingkaran masih dianggap berpengaruh dalam membentuk parameter model lokasi i. Pemilihan bandwidth optimum dapat dilakukan dengan metode Cross Validation (CV) yang didefinisikan sebagai berikut (Fotheringham et al, 2002).

$C V(h)=\sum_{i=1}^{n}\left(y_{i}-\hat{y}_{\neq i}(h)\right)^{2}$

$\hat{y}_{\neq i}(h)$ adalah nilai penaksir $y_{i}$ dimana pengamatan di lokasi $\left(u_{i}, v_{i}\right)$ dihilangkan dari proses estimasi dan $\mathrm{n}$ adalah jumlah lokasi pengamatan. Bandwidth optimum dapat diperoleh ketika nilai CV minimum.

\subsection{Model Geographically Weighted Negative Binomial Bivariate Regression}

Model Geographically Weighted Negative Binomial Bivariate Regression (GWNBBR) memiliki bentuk persamaan sebagai berikut (Ricardo \& Carvalho, 2014). 
dimana

$$
\begin{gathered}
\left(Y_{1}, Y_{2}\right) \sim B N B\left(\mu_{1}\left(u_{i}, v_{i}\right), \mu_{2}\left(u_{i}, v_{i}\right), \alpha_{1}\left(u_{i}, v_{i}\right), \alpha_{2}\left(u_{i}, v_{i}\right), \Psi\left(u_{i}, v_{i}\right)\right) \\
\mu_{j i}\left(u_{i}, v_{i}\right)=\exp \left(\mathbf{x}_{i}^{T} \boldsymbol{\beta}_{j}^{*}\right)
\end{gathered}
$$

$\mathbf{x}_{i}=\left[\begin{array}{lllll}1 & x_{1 i} & x_{2 i} & \ldots & x_{p i}\end{array}\right]^{T}$

$\boldsymbol{\beta}_{j}^{*}=\boldsymbol{\beta}_{j}\left(u_{i}, v_{i}\right)=\left[\begin{array}{llll}\beta_{j 0}\left(u_{i}, v_{i}\right) & \beta_{j 1}\left(u_{i}, v_{i}\right) & \ldots & \beta_{j p}\left(u_{i}, v_{i}\right)\end{array}\right]^{T}$

Estimasi parameter model GWNBBR menggunakan metode maksimum likelihood dengan prosedur Newton Raphson.

Pengujian signifikansi parameter secara serentak menggunakan uji devians dengan hipotesis sebagai berikut.

$H_{0}: \beta_{j 1}^{*}=\beta_{j 2}^{*}=\cdots=\beta_{j p}^{*}=0 ; k=1,2, \ldots, p ; j=1,2$

$H_{1}$ : minimal ada satu $\beta_{j k}^{*} \neq 0$

Tolak $H_{0}$ jika statistik uji $D>\chi_{[\alpha,(b-a)]}^{2}$.

$$
D=-2 \ln \left(\frac{L(\widehat{\omega})}{L(\widehat{\Omega})}\right)=2(\ln L(\widehat{\Omega})-\ln L(\widehat{\omega}))
$$

Pengujian parameter secara parsial untuk mengetahui parameter mana saja yang memberikan pengaruh signifikan terhadap model dengan hipotesis sebagai berikut.

$H_{0}: \beta_{j k}^{*}=0$

$H_{1}: \beta_{j k}^{*} \neq 0 ; k=1,2, \ldots, p ; j=1,2$

Statistik uji:

$$
z_{\text {hitung }}=\frac{\hat{\beta}_{j k}^{*}}{\operatorname{se}\left(\hat{\beta}_{j k}^{*}\right)}
$$

Tolak $H_{0}$ jika $\left|z_{\text {hitung }}\right|>z_{\alpha / 2}$ (Hilbe, 2011). Dimana $\alpha$ adalah taraf signifikansi.

\subsection{Kriteria Kebaikan Model}

Akaike Information Criterion (AIC) merupakan salah satu kriteria untuk menentukan model terbaik. Semakin kecil nilai AIC, maka model semakin baik dan layak untuk digunakan. Menurut Bozdogan (2000) AIC didefinisikan sebagai berikut:

$$
A I C=-2 \ln L(\widehat{\Omega})+2 k
$$

dimana

$L(\widehat{\Omega})$ : nilai maksimum likelihood

$k:$ jumlah parameter prediktor dalam model

\section{METODE PENELITIAN}

\subsection{Sumber Data dan Variabel Penelitian}

Data yang digunakan dalam penelitian ini adalah data sekunder tahun 2019 yang diperoleh dari Dinas Kesehatan Provinsi Jawa Tengah dan data Badan Pusat Statistik Provinsi Jawa Tengah. Unit observasi dalam penelitian ini sebanyak 35 kabupaten/kota di Jawa Tengah dengan 7 variabel.

Tabel 1. Variabel Penelitian

\begin{tabular}{|c|l|}
\hline Variabel & \multicolumn{1}{|c|}{ Keterangan } \\
\hline$Y_{1}$ & Jumlah kematian bayi \\
\hline$Y_{2}$ & Jumlah kematian ibu \\
\hline$X_{1}$ & Persentase komplikasi kebidanan yang ditangani \\
\hline$X_{2}$ & Persentase komplikasi neonatal yang ditangani \\
\hline$X_{3}$ & Persentase bayi yang diberi ASI eksklusif \\
\hline$X_{4}$ & Persentase penduduk yang tidak memiliki jaminan kesehatan \\
\hline$X_{5}$ & Persentase penduduk miskin \\
\hline
\end{tabular}




\begin{tabular}{|l|l|}
\hline$u_{i}$ & Lintang (latitude) kabupaten/kota ke-i \\
\hline$v_{i}$ & Bujur (longitude) kabupaten/kota ke-i \\
\hline
\end{tabular}

\subsection{Metode Analisis}

1. Mendeskripsikan karakteristik jumlah kasus kematian bayi dan kematian ibu di Jawa Tengah tahun 2019 beserta faktor-faktor yang memengaruhinya menggunakan pemetaan wilayah.

2. Menguji korelasi antar variabel respon $Y_{1}$ dan $Y_{2}$.

3. Menguji distribusi poisson bivariat.

4. Menguji asumsi multikolinieritas pada variabel prediktor $(X)$ berdasarkan nilai VIF.

5. Menguji overdispersi pada variabel respon $Y_{1}$ dan $Y_{2}$.

6. Memodelkan regresi binomial negatif bivariat untuk kasus jumlah kematian bayi dan kematian ibu di Provinsi Jawa Tengah tahun 2019 dengan langkah-langkah sebagai berikut.

a. Inferensi model regresi binomial negatif bivariat dengan melakukan estimasi parameter dan uji signifikansi parameter secara serentak dan parsial.

b. Menginterpretasikan model regresi binomial negatif bivariat.

7. Memodelkan GWNBBR untuk kasus jumlah kematian bayi dan kematian ibu di Provinsi Jawa Tengah tahun 2019, dengan langkah-langkah sebagai berikut.

a. Menguji heterogenitas spasial data menggunakan uji Glejser.

b. Menghitung jarak euclidean antar lokasi pengamatan berdasarkan posisi geografis dan bandwidth optimal untuk setiap lokasi pengamatan dengan menggunakan Cross Validation (CV).

c. Menghitung matriks pembobot geografis dengan menggunakan fungsi kernel adaptive bisquare.

d. Inferensi model GWNBBR dengan melakukan estimasi parameter dan uji signifikansi parameter secara serentak dan parsial.

e. Menginterpretasikan model GWNBBR yang didapatkan dan membentuk peta pengelompokan.

8. Menghitung nilai AIC regresi binomial negatif bivariat dan GWNBBR.

9. Membandingkan model regresi binomial negatif bivariat dan model GWNBBR dengan melihat nilai AIC masing-masing model. Model terbaik adalah model yang mempunyai nilai AIC terkecil.

\section{HASIL DAN PEMBAHASAN}

4.1 Karakteristik Jumlah Kasus Kematian Bayi dan Kematian Ibu di Jawa Tengah Tahun 2019

Jumlah kasus kematian bayi di Jawa Tengah tahun 2019 mencapai 4.450 kasus dengan rata-rata sebesar 127 kasus. Kematian bayi tertinggi berada di Kabupaten Brebes sebanyak 304 kasus sedangkan jumlah kasus kematian bayi terendah berada di Kota Magelang sebanyak 16 kasus. Sedangkan jumlah kasus kematian ibu di Jawa Tengah tahun 2019 mencapai 416 kasus dengan rata-rata sebesar 12 kasus. Kematian ibu tertinggi berada di Kabupaten Brebes sebanyak 37 kasus sedangkan jumlah kasus kematian bayi terendah berada di Kota Salatiga dan Kota Magelang sebanyak 2 kasus. Pola persebaran jumlah kasus kematian bayi dan kematian ibu di Jawa Tengah tahun 2019 dapat dilihat pada gambar berikut. 

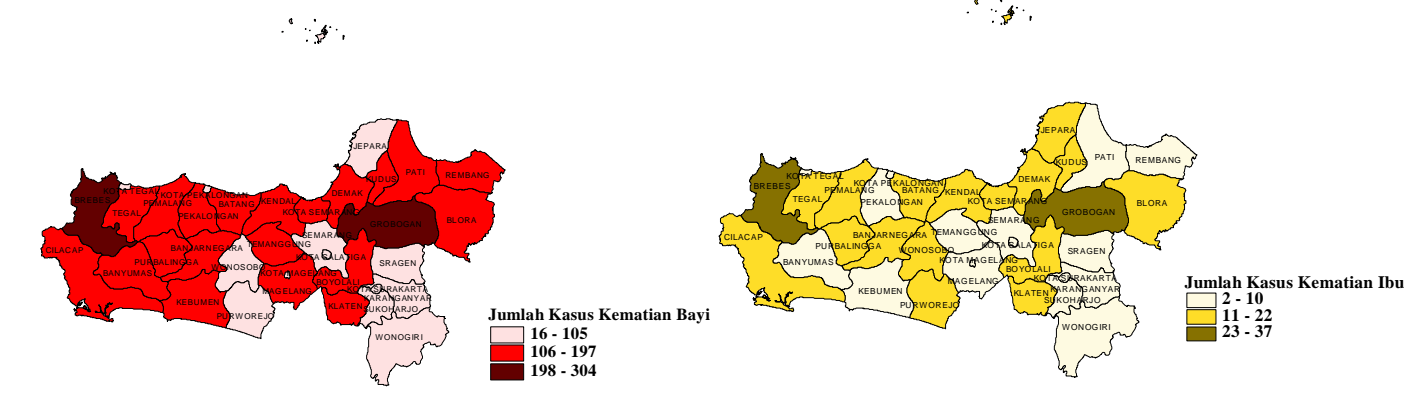

Gambar 1. Persebaran Kasus Kematian Bayi dan Kematian Ibu di Jawa Tengah 2019

\subsection{Pemeriksaan Korelasi}

Regresi bivariat dapat digunakan ketika kedua variabel respon memiliki korelasi. Pada taraf signifikansi $\alpha=0,05$ diperoleh nilai $p$-value sebesar $2,315 \times 10^{-10}<\alpha=0,05$ dan $t_{\text {hitung }}$ $=8,9657>t_{(0,025 ; 33)}=2,0345$ maka $\mathrm{H}_{0}$ ditolak sehingga disimpulkan bahwa terdapat hubungan antara jumlah kematian bayi dan jumlah kematian ibu di Jawa Tengah tahun 2019. Nilai korelasi antara variabel jumlah kematian bayi dan jumlah kematian ibu sebesar 0,842 .

\subsection{Pemeriksaan Multikolinieritas Pada Variabel Prediktor}

Salah satu syarat yang harus dipenuhi dalam pembentukan model regresi adalah tidak ada kasus multikolinieritas. Untuk mendeteksi ada atau tidaknya multikolinieritas dapat diperiksa menggunakan nilai VIF (Variance Inflation Factor). Berikut ini nilai VIF dari setiap variabel prediktor.

\begin{tabular}{cccccc}
\multicolumn{7}{c}{ Tabel 2. Nilai VIF dari Variabel Prediktor } \\
\hline Variabel & $\mathrm{X}_{1}$ & $\mathrm{X}_{2}$ & $\mathrm{X}_{3}$ & $\mathrm{X}_{4}$ & $\mathrm{X}_{5}$ \\
\hline VIF & 1,32 & 1,31 & 1,01 & 1,21 & 1,28
\end{tabular}

Berdasarkan Tabel 2 dapat diketahui bahwa nilai VIF pada semua variabel kurang dari 10. Sehingga dapat disimpulkan bahwa tidak terjadi multikolinieritas antar variabel prediktor.

\subsection{Pengujian Overdispersi}

Pada penelitian ini pengujian overdispersi dilakukan dengan membandingkan dua model, yaitu regresi poisson bivariat (BPR) dan regresi binomial negatif bivariat (BNBR). Berdasarkan hasil pengujian diperoleh bahwa $F_{\text {hit }}>F_{(0,05 ; 10 ; 10)}(7,5328>2,9782)$, maka $H_{0}$ ditolak. Artinya model BNBR berbeda signifikan dengan model BPR, hal ini menunjukkan adanya masalah overdispersi pada model regresi poisson bivariat. Sehingga perlu dilakukan penanganan menggunakan regresi binomial negatif bivariat.

\subsection{Pemodelan Regresi Binomial Negatif Bivariat}

Regresi Binomial Negatif Bivariat adalah suatu metode untuk menangani masalah overdispersion. Berikut hasil penaksiran parameter model Regresi Binomial Negatif Bivariat.

Tabel 3. Penaksiran Parameter Model Regresi Binomial Negatif Bivariat pada Kematian Bayi dan Kematian Ibu di Provinsi Jawa Tengah Tahun 2019

\begin{tabular}{|c|ccc|ccc|}
\hline \multirow{2}{*}{ Parameter } & \multicolumn{3}{|c|}{ Kematian bayi $\left(\mu_{1}\right)$} & \multicolumn{3}{c|}{ Kematian ibu $\left(\mu_{2}\right)$} \\
\cline { 2 - 7 } & Penaksiran & $Z_{\text {hitung }}$ & $p$-value & Penaksiran & $Z_{\text {hitung }}$ & $p$-value \\
\hline$\beta_{0}$ & $-1,0146$ & $-0,6964$ & 0,4862 & $-0,7183$ & $-0,4059$ & 0,6848 \\
$\beta_{1}$ & 0,0104 & 2,6106 & $0,0090^{*}$ & 0,0056 & 1,5019 & 0,1331 \\
$\beta_{2}$ & 0,0025 & 0,4195 & 0,6749 & $-0,0041$ & $-0,8136$ & 0,4159 \\
$\beta_{3}$ & 0,0488 & 3,4785 & $0,0005^{*}$ & 0,0283 & 1,6550 & 0,0979 \\
$\beta_{4}$ & 0,0001 & 0,0087 & 0,9931 & $-0,0019$ & $-0,2706$ & 0,7867 \\
$\beta_{5}$ & 0,1149 & 3,0711 & $0,0021^{*}$ & 0,0971 & 2,4496 & $0,0143^{*}$ \\
\hline
\end{tabular}

*) Signifikan dengan taraf signifikansi 5\% 
Berdasarkan Tabel 3 maka model regresi binomial negatif bivariat yang terbentuk adalah sebagai berikut.

$\hat{\mu}_{1}=\exp \left(-1,0146+0,0104 X_{1}+0,0025 X_{2}+0,0488 X_{3}+0,0001 X_{4}+0,1149 X_{5}\right)$

$\hat{\mu}_{2}=\exp \left(-0,7183+0,0056 X_{1}-0,0041 X_{2}+0,0283 X_{3}-0,0019 X_{4}+0,0971 X_{5}\right)$

Pengujian parameter pada regresi binomial negatif bivariat dilakukan secara serentak maupun parsial. Berdasarkan hasil pengujian serentak dengan taraf signifikansi 5\% diperoleh nilai $D(\widehat{\boldsymbol{\beta}})=44,4084$ lebih besar dari $\chi_{(0,05 ; 10)}^{2}$ sebesar 18,31 maka tolak $\mathrm{H}_{0}$ yang berarti paling sedikit ada satu variabel prediktor berpengaruh terhadap model. Sehingga model (5) dan (6) dapat digunakan. Selanjutnya pengujian secara parsial dengan taraf signifikansi $5 \%$ diperoleh $Z_{(0,025)}$ sebesar 1,96 maka diperoleh tiga variabel yang memberikan pengaruh secara signifikan terhadap jumlah kasus kematian bayi di Jawa Tengah, antara lain persentase komplikasi kebidanan yang ditangani $\left(\mathrm{X}_{1}\right)$, persentase bayi yang diberi ASI eksklusif $\left(\mathrm{X}_{3}\right)$, dan persentase penduduk miskin $\left(\mathrm{X}_{5}\right)$. Sedangkan satu variabel yang memberikan pengaruh secara signifikan terhadap jumlah kasus kematian ibu di Jawa Tengah, yaitu persentase penduduk miskin $\left(\mathrm{X}_{5}\right)$.

\subsection{Pengujian Heterogenitas Spasial}

Berdasarkan hasil pengujian heterogenitas spasial diperoleh nilai statistik uji Glejser sebesar 19,6801. Pada taraf signifikansi 5\% diperoleh $\chi_{(0,05 ; 10)}^{2}$ sebesar 18,31, maka dapat disimpulkan bahwa terdapat masalah heterogenitas spasial pada kasus kematian bayi dan kematian ibu di Jawa Tengah tahun 2019. Oleh karena itu perlu dilakukan pengembangan metode regresi binomial negatif bivariat yang memperhatikan faktor spasial yang disebut dengan metode GWNBBR.

\subsection{Pemodelan Geographically Weighted Negative Binomial Bivariate Regression (GWNBBR)}

Pemodelan GWNBBR menghasilkan model yang berbeda-beda tiap wilayah. Sebagai contoh akan disajikan pemodelan GWNBBR pada lokasi penelitian yang ke-1 $\left(u_{1}, v_{1}\right)$ yaitu Kabupaten Cilacap.

Tabel 4. Penaksiran Parameter Model GWNBBR di Kabupaten Cilacap pada

Kematian Bayi dan Kematian Ibu di Provinsi Jawa Tengah Tahun 2019

\begin{tabular}{|c|ccc|ccc|}
\hline \multirow{2}{*}{ Parameter } & \multicolumn{3}{|c|}{ Kematian bayi $\left(\mu_{1}\right)$} & \multicolumn{3}{c|}{ Kematian ibu $\left(\mu_{2}\right)$} \\
\cline { 2 - 7 } & Penaksiran & $Z_{\text {hitung }}$ & $p$-value & Penaksiran & $Z_{\text {hitung }}$ & $p$-value \\
\hline$\beta_{0}$ & $-1,2597$ & $-1,8788$ & 0,0603 & $-1,1861$ & $-1,1087$ & 0,2676 \\
$\beta_{1}$ & 0,0101 & 1,6895 & 0,0911 & 0,0051 & 0,8519 & 0,3943 \\
$\beta_{2}$ & 0,0059 & 0,6247 & 0,5322 & $-0,0017$ & $-0,2200$ & 0,8259 \\
$\beta_{3}$ & 0,0474 & 4,4042 & $0,0000^{*}$ & 0,0289 & 4,0377 & $0,0001^{*}$ \\
$\beta_{4}$ & 0,0117 & 0,9366 & 0,3489 & $-0,0005$ & $-0,0365$ & 0,9709 \\
$\beta_{5}$ & 0,0915 & 1,6652 & 0,0959 & 0,1215 & 2,2808 & $0,0226^{*}$ \\
\hline
\end{tabular}

*) Signifikan dengan taraf signifikansi 5\%

Berdasarkan Tabel 4 maka model GWNBBR di Kabupaten Cilacap yang terbentuk adalah sebagai berikut.

$\hat{\mu}_{1}=\exp \left(-1,2597+0,0101 X_{1}+0,0059 X_{2}+0,0474 X_{3}+0,0117 X_{4}+0,0915 X_{5}\right)$

$\hat{\mu}_{2}=\exp \left(-1,1861+0,0051 X_{1}-0,0017 X_{2}+0,0289 X_{3}-0,0005 X_{4}+0,1215 X_{5}\right)$

Pengujian parameter GWNBBR dilakukan secara serentak maupun parsial. Berdasarkan hasil pengujian serentak dengan taraf signifikansi 5\% diperoleh nilai $D(\widehat{\boldsymbol{\beta}})=38,1998$ lebih besar dari $\chi_{(0,05 ; 10)}^{2}$ sebesar 18,31 maka tolak $\mathrm{H}_{0}$ yang berarti paling sedikit ada satu variabel prediktor berpengaruh terhadap model. Sehingga model (7) dan (8) dapat digunakan. Selanjutnya pengujian secara parsial dengan taraf signifikansi $5 \%$ diperoleh $z_{(0,025)}$ sebesar 
1,96 maka diperoleh satu variabel yang memberikan pengaruh secara signifikan terhadap jumlah kasus kematian bayi di Kabupaten Cilacap, yaitu persentase bayi yang diberi ASI eksklusif $\left(\mathrm{X}_{3}\right)$. Sedangkan variabel yang memberikan pengaruh secara signifikan terhadap jumlah kasus kematian ibu di Kabupaten Cilacap, yaitu persentase bayi yang diberi ASI eksklusif $\left(\mathrm{X}_{3}\right)$ dan persentase penduduk miskin $\left(\mathrm{X}_{5}\right)$.

Pada wilayah lain dengan cara yang sama diperoleh pengelompokan dengan variabel yang signifikan sama pada kasus kematian bayi dan kematian ibu masing-masing disajikan pada Tabel 5 dan Tabel 6 sebagai berikut.

Tabel 5. Pengelompokan Kabupaten/Kota Berdasarkan Signifikansi Parameter Pada Kasus Kematian Bayi

\begin{tabular}{|c|c|c|c|}
\hline Kelompok & Kabupaten/Kota & $\begin{array}{c}\text { Variabel yang } \\
\text { Signifikan }\end{array}$ & Jumlah \\
\hline 1 & $\begin{array}{l}\text { Kab. Banyumas, Kab. Boyolali, Kab. } \\
\text { Karanganyar, Kab. Sragen, Kab. Demak, Kab. } \\
\text { Temanggung, Kab. Pekalongan, Kota Surakarta }\end{array}$ & $\mathrm{X}_{1}, \mathrm{X}_{3}$ & 8 \\
\hline 2 & $\begin{array}{l}\text { Kab. Cilacap, Kab. Magelang, Kab. Klaten, } \\
\text { Kab Wonogiri, Kab. Blora, Kab. Rembang, } \\
\text { Kab. Semarang, Kab. Tegal, Kota Salatiga }\end{array}$ & $\mathrm{X}_{3}$ & 9 \\
\hline 3 & Kab. Banjarnegara, Kab. Kudus & $\mathrm{X}_{1}, \mathrm{X}_{5}$ & 2 \\
\hline 4 & $\begin{array}{l}\text { Kab. Purbalingga, Kab. Purworejo, Kab. } \\
\text { Wonosobo, Kab. Jepara, Kab. Kendal, Kab. } \\
\text { Batang, Kab. Pemalang, Kota Magelang }\end{array}$ & $\mathrm{X}_{3}, \mathrm{X}_{5}$ & 8 \\
\hline 5 & Kota Pekalongan & $\mathrm{X}_{5}$ & 1 \\
\hline 6 & $\begin{array}{l}\text { Kab. Kebumen, Kab. Sukoharjo, Kab. } \\
\text { Grobogan, Kab. Pati, Kab. Brebes, Kota } \\
\text { Semarang, Kota Tegal }\end{array}$ & - & 7 \\
\hline
\end{tabular}

Tabel 6. Pengelompokan Kabupaten/Kota Berdasarkan Signifikansi Parameter Pada Kasus Kematian Ibu

\begin{tabular}{|c|c|c|c|}
\hline Kelompok & Kabupaten/Kota & $\begin{array}{l}\text { Variabel } \\
\text { Signifikan }\end{array}$ & Jumlah \\
\hline 1 & Kab. Temanggung, Kab. Brebes & $\mathrm{X}_{1}$ & 2 \\
\hline 2 & Kab. Wonosobo & $\mathrm{X}_{1}, \mathrm{X}_{3}$ & 1 \\
\hline 3 & Kab. Pekalongan & $\mathrm{X}_{1}, \mathrm{X}_{5}$ & 1 \\
\hline 4 & Kab. Kendal & $\mathrm{X}_{2}, \mathrm{X}_{5}$ & 1 \\
\hline 5 & $\begin{array}{l}\text { Kab. Cilacap, Kab. Banyumas, Kab. } \\
\text { Purbalingga, Kab. Pemalang, Kab. Tegal }\end{array}$ & $\mathrm{X}_{3}, \mathrm{X}_{5}$ & 5 \\
\hline 6 & Kab. Banjarnegara, Kab. Purworejo & $\mathrm{X}_{5}$ & 2 \\
\hline 7 & $\begin{array}{l}\text { Kab. Kebumen, Kab. Magelang, Kab. Boyolali, } \\
\text { Kab Klaten, Kab. Sukoharjo, Kab. Wonogiri, } \\
\text { Kab. Karanganyar, Kab. Sragen, Kab. } \\
\text { Grobogan, Kab. Blora, Kab. Rembang, Kab. } \\
\text { Pati, Kab. Kudus, Kab. Jepara, Kab. Demak, } \\
\text { Kab. Semarang, Kab. Batang, Kota Magelang, } \\
\text { Kota Surakarta, Kota Salatiga, Kota Semarang, } \\
\text { Kota Pekalongan, Kota Tegal }\end{array}$ & - & 23 \\
\hline
\end{tabular}

\subsection{Pemilihan Model Terbaik}

Pemilihan model terbaik berdasarkan kriteria AIC pada model regresi binomial negatif bivariat dan GWNBBR adalah sebagai berikut. 
Tabel 7. Pemilihan Model Terbaik dengan AIC

\begin{tabular}{lc}
\hline \multicolumn{1}{c}{ Model } & AIC \\
\hline Regresi Binomial Negatif Bivariat & 687,019 \\
GWNBBR & 674,321 \\
\hline
\end{tabular}

Tabel 7 menunjukkan bahwa dari kedua model tersebut GWNBBR memiliki AIC lebih kecil dibandingkan dengan regresi binomial negatif bivariat, sehingga GWNBBR lebih baik dalam memodelkan jumlah kasus kematian bayi dan kematian ibu di masing-masing kabupaten/kota di Jawa Tengah tahun 2019.

\section{KESIMPULAN}

Pada tahun 2019 kasus kematian bayi dan kematian ibu di Jawa Tengah terjadi di seluruh kabupaten/kota. Jumlah kasus kematian bayi tertinggi berada di Kabupaten Brebes sebanyak 304 kasus, sedangkan jumlah kasus kematian bayi terendah berada di Kota Magelang sebanyak 16 kasus. Jumlah kasus kematian ibu tertinggi berada di Kabupaten Brebes sebanyak 37 kasus, sedangkan jumlah kasus kematian ibu terendah berada di Kota Salatiga dan Kota Magelang sebanyak 2 kasus. Pemodelan jumlah kasus kematian bayi dan kematian ibu menggunakan regresi binomial negatif bivariat diperoleh hasil bahwa terdapat tiga variabel yang memberikan pengaruh secara signifikan terhadap jumlah kasus kematian bayi, diantaranya persentase komplikasi kebidanan yang ditangani $\left(\mathrm{X}_{1}\right)$, persentase bayi yang diberi ASI eksklusif $\left(\mathrm{X}_{3}\right)$, dan persentase penduduk miskin $\left(\mathrm{X}_{5}\right)$. Sedangkan satu variabel yang memberikan pengaruh secara signifikan terhadap jumlah kasus kematian ibu, yaitu persentase penduduk miskin $\left(\mathrm{X}_{5}\right)$.

Pemodelan jumlah kasus kematian bayi dan kematian ibu menggunakan GWNBBR dengan fungsi pembobot Adaptive Kernel Bisquare diperoleh pengelompokan berdasarkan variabel yang signifikan. Pada kematian bayi diperoleh 6 kelompok, sedangkan kematian ibu diperoloh 7 kelompok.

Pemodelan menggunakan GWNBBR diperoleh nilai AIC lebih kecil daripada BNBR. Sehingga dapat dikatakan bahwa metode GWNBBR lebih baik untuk memodelkan jumlah kasus kematian bayi dan kematian ibu di Jawa Tengah.

\section{DAFTAR PUSTAKA}

Best, D. J. 1999. Tests of fit and other nonparametric data analysis. Thesis. University of Wollongong.

Bozdogan, H. 2000. Akaike's Information Criterion and Recent Developments in Information Complexity. Journal of Mathematical Psychology Vol. 44, No. 1: Hal. 6291.

Cameron, A.C., Trivedi, P. K. 1998. Regression Analysis of Count Data. New York: Cambridge University Press.

Chasco, C., García, I., Vicéns, J. 2008. Modeling Spatial Variations in Household Disposable Income with Geographically Weighted Regression. Munich Personal RePEc Archive Paper No. 9581.

[Dinkes Jateng] Dinas Kesehatan Provinsi Jawa Tengah. 2019. Profil Kesehatan Provinsi Jawa Tengah Tahun 2018. Semarang: Dinas Kesehatan Provinsi Jawa Tengah.

Draper, N. R., Smith, H. 1998. Applied Regression Analysis Third Edition. Canada: John Wiley and sons, Inc.

Famoye, F. 2010. On The Bivariate Negative Binomial Regression Model. Journal of Applied Statistics Vol. 37, No. 6: Hal. 969-981.

Fitriyanti, W., Kurniawan, U. 2019. Regresi Negatif Binomial Bivariat untuk Mengatasi Overdispersi Regresi Poisson Bivariat. Statistika Vol. 7, No. 1: Hal. 39-46. 
Fotheringham, A.S. Brundson, C. dan Charlton, M. 2002. Geographically Weighted Regression. UK: John Wiley and Sons, Chichester.

Gujarati, D. N. 2003. Basic Econometrics Fourth Edition. New York: The McGraw Hill Companies.

Hilbe, J. M. 2011. Negative Binomial Regression Second Edition. New York: Cambridge University Press.

Johnson, R. A., Wichern, D. W. 2007. Applied Multivariate Statistical Analysis. USA: Pearson Practice Hall.

Karlis, D., Ntzoufras, I. 2005. Bivariate Poisson and Diagonal Inflated Bivariate Poisson Regression Models in R. Journal of Statistical Software Vol. 14, No. 10:Hal. 1-36.

[Kemenkes RI] Kementerian Kesehatan Republik Indonesia. 2020. Profil Kesehatan Indonesia Tahun 2019. Jakarta: Kementerian Kesehatan Republik Indonesia.

Long, J. S. 1997. Regression Models for Categorical and Limited Dependent Variables. California: Sage Publications.

McClave, J. T., Benson, P.G., Sincich, T. 2018. Statistics for Business and Economics Thirteenth Edition. United Kingdom: Pearson Education Inc.

Prahutama, A., Sudarno, Suparti, Mukid, M. A. 2017. Analisis Faktor-Faktor yang Mempengaruhi Angka Kematian Bayi di Jawa Tengah Menggunakan Regresi Generalized Poisson dan Binomial Negatif. Statistika Vol. 5, No. 2: Hal. 1-6.

Ricardo, A. \& Carvalho, T. 2014. Geographically Weighted Negative Binomial Regression-Incorporating Overdispersion. Springer Vol. 24: Hal. 769-783. 